\title{
Small Cell Lung Cancer: Current and Future Strategies
}

\author{
Sofia Lampaki ${ }^{1}$, Paul Zarogoulidis ${ }^{1 凶}$, Kalliopi Lagoudi ${ }^{1}$, Drosos Tsavlis ${ }^{1}$, Ioannis Kioumis ${ }^{1}$, Elena \\ Papakala ${ }^{1}$, George Lazaridis'², Haidong Huang 3 , Wolfgang Hohenforst-Schmidt ${ }^{4}$, Pavlos Pavlidis 5 , Kaid \\ Darwiche6, Nikolaos Barbetakis7, Ilias Karapantzos8, Chrysa Karapantzou8, Aggeliki Rapti 9 , Vasilis \\ Karavasilis $^{2}$, Konstantinos Zarogoulidis ${ }^{1}$ \\ 1. Pulmonary Department-Oncology Unit, “G. Papanikolaou” General Hospital, Aristotle University of Thessaloniki, Thessaloniki, Greece; \\ 2. Oncology Department, "G. Papageorgiou" University Hospital, Thessaloniki, Greece. \\ 3. Department of Respiratory Diseases, Changhai Hospital/First Affiliated Hospital of the Second Military Medical University, Shanghai, China. \\ 4. Medical Clinic I, "Fuerth" Hospital, University of Erlangen, Fuerth, Germany. \\ 5. Forensic Department, University General Hospital of Alexandroupolis, Democritus University of Thrace, Alexandroupolis, Greece. \\ 6. University Pulmonary Department-Interventional Unit, "Ruhrland" Clinic, University of Duisburg-Essen, Essen, Germany. \\ 7. Thoracic Surgery Department, "Theageneio" Anticancer Hospital, Thessaloniki, Greece; \\ 8. Ear, Nose and Throat Department, "Saint Luke" Private Hospital, Panorama, Thessaloniki, Greece; \\ 9. Second Pulmonary Clinic, 'Sotiria' Chest Diseases Hospital, Athens, Greece.
}

Corresponding author: Paul Zarogoulidis, Pulmonary Department, "G. Papanikolaou" General Hospital, Aristotle University of Thessaloniki. Thessaloniki, Greece. Fax: 00302130992433 Mobile: 004915779211742 Email: pzarog@hotmail.com.

(C) Ivyspring International Publisher. This is an open access article distributed under the terms of the Creative Commons Attribution (CC BY-NC) license (https://creativecommons.org/licenses/by-nc/4.0/). See http://ivyspring.com/terms for full terms and conditions.

Received: 2016.07.11; Accepted: 2016.07.28; Published: 2016.08.01

\begin{abstract}
Small cell lung cancer (SCLC) represents approximately $15 \%$ of all lung cancer diagnoses and over the last 20 years, in the Western world, the proportion of patients with SCLC has decreased to $13 \%$ due to world campaign for smoking cessation. Due to high growth fraction of the disease, to early dissemination with widespread metastases and also to early development of drug resistance, the treatment of SCLC remains discouraging. The median survival time without treatment is $2-4$ months and with treatment the 5 -year survival rate remains low at $<7 \%$ overall and the most of the patients relapse within one year after first-line treatment. Chemotherapy with a platinum regimen and etoposide is the gold of standard of treatment for limited (LD) and extensive disease (ED), by adding radical thoracic radiotherapy for patients with good performance status, with LD. The new TNM classification should be used also for SCLC. For the patients who have any response is indicated the prophylactic cranial irradiation $(\mathrm{PCl})$ due to high risk of brain metastases. The benefit from second-line therapy is limited and maintenance therapy did not appear to improve overall survival (OS) or progression free survival (PFS) for patients with SCLC. Many targeted agents have been investigated in LD and ED, almost all of them in unselected populations, but also with pessimistic results. Due to unchanged therapeutic options for almost four decades, is required desperately to understand better the molecular basis of SCLC and to proceed in to clinical trials for new drugs and targeted agents.
\end{abstract}

Key words: Small cell lung cancer, strategies

\section{Introduction}

Small cell lung cancer (SCLC) is a neuroendocrine tumor that accounts for approximately $15 \%$ of all cases of lung cancer. The new cases that are estimated in the United States in 2015 were 221,200 and the deaths from lung cancer were 158,040. [1] Lung cancer may be diagnosed with symptoms or it can be found casually on chest imaging. From patients with SCLC, about 30\% of them, they will have limited-stage disease (LD). [2] This means that the tumors of these patients are 
restricted to the hemithorax of origin, the mediastinum, or the supraclavicular lymph nodes. When the tumors are spread beyond the supraclavicular areas, then these patients have extensive-stage disease (ED). Patients with distant metastases are also considered to have ED. [3,4]

The American Joint Committee on Cancer (AJCC) Tumor, Node, and Metastasis (TNM) defines LD as any T, except for T3-4, any N, and M0 (due to LD the disease must fit in a tolerable radiation field). [5] This corresponds to TNM stages I to IIIB. Extensive disease is TNM stage IV with distant metastases (M1) and includes the malignant pleural effusions. [3,4] The limited stage of disease is a favourable prognostic factor. Good prognostic factors also are the good performance status, the female sex and the age $<50$ years old. [2] Also the smoking cessation improves survival and the smoking prevention will undoubtedly remain the primary and most important intervention to further decrease mortality. [5] The median survival time for patients with SCLC without treatment is between 2 and 4 months. For the patients with limited disease and who submitted in treatment the median survival is $15-20$ months and for those with extensive disease the survival reduced in 7-11 months. [6] Not very often, patients with SCLC may develop paraneoplastic syndromes like Cushing syndrome from secretion of adrenocorticotropic hormone, inappropriate antidiuretic hormone secretion, Lambert-Eaton myasthenic syndrome or paraneoplastic cerebellar degeneration. [7] Also due to physical examination may noticed supraclavicular lymphadenopathy, and some of these patients could present signs of chronic obstructive pulmonary disease or pneumonia. The pathologic classification of SCLC includes the Small Cell Lung Carcinoma and the combined small cell carcinoma. [8] SCLC arising from neuroendocrine cells and the neuroendocrine tumors include the typical carcinoid, low grade, the atypical carcinoid, intermediate grade and the neuroendocrine tumors, high grade. The SCLC comprised to the high grade, neuroendocrine tumors. SCLC is a carcinoma that is composed of small round, oval or spindle shaped cells with scanty cytoplasm. These carcinomas are discrete by their finely granular nuclei salt and pepper chromatin and by nuclear molding with small inconspicuous nucleoli. [9] In small biopsies there are fragmentation and crush artifact. Immuno-histochemistry is positive for neuroendocrine markers as neuron specific enolase, neyral cell adhesion molecule (NCAM) (DD56), Leu-7 (CD57) and synaptophysin. The expression of dopa decarboxylase, insulin-like growth factor 1, calcitonin, neuron-specific enolase, CD56, chromogranin A and gastrin-releasing peptide are noticed in neuroendocrine and neural differentiation. To the $75 \%$ of cases with SCLC could be observed one or more markers of neuroendocrine differentiation. [10] Concerning preinvasive or in situ malignant changes are very infrequent in tumors with SCLC. [11]

\section{Treatment Option for SCLC}

Standard treatment options are described in Table 1.

Table 1. Standard treatment options for patients with SCLC.

\begin{tabular}{ll}
\hline Stage & Standard Treatment Options \\
\hline Limited-stage disease & $\begin{array}{l}\text { Chemotherapy and radiation therapy } \\
\text { Combination chemotherapy alone } \\
\text { Surgery followed by chemotherapy or } \\
\text { chemoradiation therapy } \\
\text { Prophylactic cranial irradiation } \\
\text { Extensive-stage disease }\end{array}$ \\
$\begin{array}{l}\text { Combination chemotherapy } \\
\text { Radiation therapy } \\
\text { Pecurrent disease }\end{array}$ & $\begin{array}{l}\text { Prophylactic cranial irradiation } \\
\text { Chemotherapy } \\
\text { Palliative therapy }\end{array}$ \\
\hline
\end{tabular}

\section{Standard Treatment Options for Patients with Limited-Stage SCLC}

\section{Surgery}

A very small percentage of people who have limited-stage small cell lung cancer and no lymph node tumors may benefit from surgery, after which adjuvant chemotherapy is given. [12-16] The stage of disease of these patients is T1, $2 \mathrm{~N} 0,1 \mathrm{M} 0$, they have a more favorable outcome and 5-year survival rates of $50 \%$ have been reported with surgery. In patients who receive chemoradiotherapy, with the addition of surgery, there is no evidence of improvement in survival. [16] In patients with clinical T1-2 N0-1, who are candidates for surgery, meticulous mediastinal node exploration should be performed. Surgery may be indicated in patients with absence of mediastinal involvement and resection should be followed by adjuvant chemotherapy. Postoperative radiotherapy must be considered for pathologic N1 and unforeseen N2 disease. (Table 2)

Table 2. Tumor stages.

\begin{tabular}{lllllll}
\hline \multicolumn{2}{ll}{ SCLC } \\
\multicolumn{2}{ll}{ Limited Disease } \\
\hline N0 & N0 & N1 & N1 & N2 & N3 & Any \\
IA & IB & IIA & IIB & IIIA & IIIB & IV \\
\multicolumn{2}{ll}{ Surgery } & & & No surgery & \\
\hline
\end{tabular}




\section{Chemotherapy and radiation therapy}

Chemotherapy and radiation therapy have demonstrated that they improve survival for patients with SCLC. Chemotherapy may improve the survival of patients with LD or ED, but the cure achieved only in a small number of cases. $[17,18]$ Surgical resection of tumor or radiation therapy very rare lead to long term survival due to the fact that patients with SCLC are inclined to present distant metastases. [14] Combined-modality treatment with concurrent chemotherapy with etoposide and cisplatin with thoracic radiation therapy (TRT) is the treatment of choice for patients with LD SCLC, meaning patients with T1-4, N0-3 M0 tumours who are in a good performance. There were also prospective randomized trials, whose results showed that the combined-modality therapy offers a better survival (5\% at 3 years), compared with chemotherapy alone. $[2,19,20]$ There are also clinical trials that they showed median survivals of 18 to 24 months and $40 \%$ to $50 \%$ 2-year survival rates with less than a $3 \%$ treatment-related mortality.[2,21-24] There are studies that they didn't show benefit from increased dose intensity, from the administration of an additional drug to etoposide and to the platinum-based agent or from maintenance chemotherapy. [24-32] In patients with good performance status, the thoracic radiotherapy should be initiated with the first or second cycle, of chemotherapy. [33-36] There is an analysis which includes four trials, in which the therapy completed in less than 30 days and this fact was associated with an improved 5-year survival rate. [25] Concerning the chest radiation have been used 2 schedules in one randomized study. The schedule to one of them was with once daily chest radiation and the other one was with twice daily chest radiation. This study showed a survival advantage for the group of twice-daily radiation therapy given for 3 weeks compared with once-daily radiation therapy to $45 \mathrm{~Gy}$ given for 5 weeks $(p=0.04)[30,37]$ But due to increased toxic effects from the twice-daily radiotherapy, like increased esophagitis, this type of radiation has not been widely used. The usually used radiotherapy schedule is the once-daily fractions to higher doses of greater than 60 Gy. [38-42]

\section{Combination chemotherapy alone}

For the patients who there is a contraindication to radiation therapy they will submit only in chemotherapy. For the patients who present superior vena cava syndrome they submitted immediately in chemotherapy, in radiotherapy or in both depending on the clinical situation of patient.
Patients with a contraindication to radiation therapy, such as acute infection, failure, severe pulmonary insufficiency of compensatory lung cancer, peripheral blood leukocytes less than $4 \times 106 / 1$ or platelets less than $80 \times 106 / 1$, could be treated with chemotherapy alone. The recommended treatment of patients with superior vena cava syndrome at presentation is chemotherapy, radiation therapy, or both, in a combination, depending on the severity of symptoms of the syndrome, in order to reduce the tumour that is causing the obstruction. $[43,44]$

\section{PCI}

The prophylactic cranial irradiation $(\mathrm{PCI})$ is performed after the delivery of chemotherapy in order to minimize the risks of neurotoxicity. It is associated with alopecia and a short-term decrease in quality of life. The risk to present patients with SCLC, central nervous system (CNS) metastases could be reduced by more than $50 \%$ by the administration of PCI. [45] All patients with T1-4, N0-3 M0 disease without disease progression after treatment and who have a good PS should be considered for administration of PCI. Patients with SCLC have a $60 \%$ risk of developing CNS metastases to the next 2 - 3 years after starting treatment. [16,46] Most of the patients with SCLC they develop only brain metastasis and they die due to this metastasis.

\section{Neurologic affect}

It is noticeable that there are some retrospective studies that have been showed that the patients who leave more than 2 years, regardless if they submit in PCI [46], they present a high of developing neurocognitive side effects, especially patients $>65$ years old and/or with important vascular disease. $[16,46]$

\section{Extensive-Stage SCLC Treatment}

The standard of care for patients with ED SCLC is the combination of platinum based drug and etoposide, as in LD SCLC. Because cisplatin is associated with increased toxic effects requires a big amount of fluid hydration and this may be a major problem for cardiovascular patients, so it is preferably used carboplatin, which is also active in SCLC, and the dosage adapted to the renal function of the patient and has fewer toxic effects. Most of the patients, when they diagnosed with ED of SCLC, have reduced performance status. To this group of patients favored to be administered single agents and low dose regimens. Nevertheless, the prognosis is poor. What applies for the performance status did not for the age of patients? The data shows that there is no difference 
in RR or in PFS or in OS of older patients compared with those that are younger. The standard chemotherapy combinations become tolerate and to the older patients. The performance status most of the patients ED SCLC is significant low and the prognosis of these patients is poor. Due to the fact that the chemotherapy meliorates the survival, the question is the kind of chemotherapy schema. The recommended chemotherapy is single agent chemotherapy, either intravenous or oral, and semimonthly regimens in low dose. [4,7] Patients in elderly at the time of diagnosis presented medical characteristics making difficult the selection of treatment. The available data show that when the geriatric patients, who are in good clinical condition, with good performance status $(0-1)$, normal liver and renal function and they are not under polypharmacy, receive the recommended chemotherapy schema, as the general population, they have the same DFS and OS as the general population. [40] There are also and other regimens that are less common in use, as cisplatin and irinotecan, ifosfamide, cisplatin and etoposide, cyclophosphamide, doxorubicin and etoposide, cyclophosphamide, doxorubicin, etoposide and vincristine, cyclophosphamide, etoposide and vincristine, ad also cyclophosphamide, doxorubicin and vincristine. (Table 3)

Table 3. Combination Chemotherapy for Extensive-Stage SCLC.

\begin{tabular}{ll}
\hline Standard & Etoposide + carboplatin \\
\cline { 2 - 2 } treatment & Etoposide + cisplatin \\
\hline Other regimens & Cisplatin + irinotecan \\
& Ifosfamide + cisplatin + etoposide \\
& Cyclophosphamide + doxorubicin + etoposide \\
& Cyclophosphamide + doxorubicin + etoposide + \\
& vincristine \\
& Cyclophosphamide + etoposide + vincristine \\
& Cyclophosphamide + doxorubicin + vincristine \\
\hline
\end{tabular}

The patients with ED SCLC showed overall response rate of $50 \%$ to $80 \%$ and complete response rates of $0 \%$ to $30 \%$. $[47,48]$ There are 2 meta-analyses that they estimate the platinum based combinations versus the non-platinum. The one of them, a meta-analysis of 19 clinical trials, showed a benefit in survival for the patients who received a platinum based therapy. [48] The other one, a Cochrane analysis, did not show any survival difference. [49] Another trial was this from the Hellenic Oncology Group, a phase III trial, in which the patients randomized to receive cisplatin and etoposide or carboplatin plus etoposide. [50] In the cisplatin arm the median survival was 11.8 months and in the carboplatin 12.5 months.

\section{Combination chemotherapy regimens}

The results from 5 trials and two meta-analyses have been assessed, in which compared the combination of etoposide and cisplatin versus irinotecan and cisplatin. No one trial show superiority of some combination except from one that conducted in Japanese people, and it showed superiority the combination with irinotecan and cisplatin. [50] From all the trials the conclusion was the clinical benefit was equivalent. The difference that noticed was due to the toxicity profiles. [51,52] No inferiority for survival also showed and a randomized trial, in which the patients randomized to receive oral topotecan and cisplatin or etoposide and cisplatin. [53] Also not reported improvement to OS when added and a third regimen, as paclitaxel to etoposide and cisplatin, ifosfamide to cisplatin and etoposide, thalidomide to carboplatin and etoposide, bevacisumab to carboplatin or to cisplatin. [54-58]

\section{Duration of chemotherapy}

The results from several trials demonstrates that more than 5 to 6 chemotherapy cycles do not increase the survival. [29,59]

\section{Maintenance for SCLC}

The results from 11 randomized trials considered marginally effective the maintenance therapy $(\mathrm{HR}=0.89, \mathrm{p}=0.02)$. [60] Also, from 14 randomized trials, was reported increase of OS of $9 \%$ in 1-year and $4 \%$ in 2-year OS. [61] A noticeable trial is this one with sunitinib. A phase II trial in which patients randomized to receive sunitinib or placebo after 4-6 cycles of chemotherapy with cisplatin or carbo and etoposide. The PFS on maintenance arm was 2.3 versus 3.8 months for those who receive sunitinib (HR=1.53; 90\% CL: 0.97-1.78; $\mathrm{p}=0.27)$. [62]

\section{Dose intensity chemotherapy}

There have been studies that did not report consistently improvement in OS and the data showed that the high doses associated with significant toxicity. [63-66] However; there are studies that they report improvement in OS with a modest increase in dose intensity of $25 \%-34 \%$. [63,67-69] Therefore the role of dose intensification in patients who receive chemotherapy for SCLC remains ambiguous.

\section{Radiation therapy}

The treatment of choice is the radiation therapy for the patients with extensive disease, for the metastatic sites and especially for the bones, the 
epidural, and the brain, which in this case the patients are treated with whole-brain radiation therapy. [70] The group of patients, with extensive disease, who submitted in chemotherapy and they revealed any response, they should be undergo assessment for thoracic radiation therapy. There is a big randomized trial, in which almost 500 patients after completing the chemotherapy schema, they randomized to receive radiation therapy or observation. For the patients who submitted in radiotherapy, the 2-year OS was $13 \%$ (95\% CI, 9-19) and for those who not only 3\% group (95\% CI, 2-8; $\mathrm{p}=0.004)$ and the PFS was $24 \%(95 \% \mathrm{CI}$, 19-30) versus $7 \% \quad(95 \% \quad \mathrm{CI}, 4-11 ; \mathrm{p}=0.001)$, respectively. [71] Patients with good performance status, without progression, they should be offered PCI, in 10 fractions with TD 25 Gy. In a randomized trial of 286 patients, after they completed the chemotherapy (4 or 6 cycles), they randomized to be submitted in PCI or observation only. Into the first year the risk of brain metastasis for those who received PCI was $14.6 \%$ (95\% CI, 8.3-20.9) and for those who not the risk elevated to the $40.4 \%(95 \% \mathrm{CI}$, 32.1- 48.6). [72] Although PCI increases long term survival the patients $>65$ years old and/or with important vascular disease they have elevated risk of developing neurocognitive side effects. [73]

\section{Recurrent SCLC Treatment}

\section{Chemotherapy}

SCLC recurs in the most of the patients, even though most of them respond to first-line therapy. The majority of the patients relapse after 1-2 years after 1st line chemotherapy. The median survival after 2nd line therapy is less than 6 months. The selection of patients with treatment with 2 nd line therapy is based on treatment-free survival, on extent of response to 1st line therapy, on residual toxicity from 1st line therapy and as in every treatment on performance status. The patients who receive 2 nd line treatment have better outcomes than those on best supportive care. But only $32 \%$ of patients with relapsed disease may receive 2 nd line chemotherapy. [74] The patients divided in 2 categories, sensitive and resistant. Patients with sensitive disease have an interval from 1st line response more than 3 months and there is evidence of survival benefits and improvement of symptoms for this group of patients. [75] It has been shown that the sensitive patients respond to the initial regimen combination in almost $50 \%$. [76] Resistant are patients whom PFS is less than 3 months. And there are and the refractory patients which they are not responding or progressing during chemotherapy. For these patients the outcome is very poor and the clinical benefit of further systemic therapy is limited. The standard of chemotherapy for recurrent disease is the topotecan, a topo 1 inhibitor. A randomized, phase III trial, showed that in the 2nd line, in chemosensitive disease, the oral and the I.V. topotecan have the same efficacy, but they have different toxicity profile. The median survival for the patients who received oral topotecan was 33 weeks, and for those who receive it intravenously 35 weeks. For oral topotecan the 1st year survival was $32.6 \%$ and the 2 nd $12.4 \%$, and respectively for i.v. topotecan was $29.2 \%$ and $7.1 \%$. [77] A phase III trial comparing oral topotecan with best supportive care (BSC) showed that the patients of the arm with oral topotecan had better OS, 25.9 weeks versus 13.9 weeks (HR 0.64, $\mathrm{p}=0.01$ ) and also better symptom control. [75] Another phase III randomized trial, for the second line therapy, compared topotecan with cyclophosphamide, doxorubicine and vincristine. The efficacy was equal with similar RRs, TTP and OS. [78] Several clinical trials of cytotoxic chemotherapies and molecular targeted agents investigated in the treatment of relapsed SCLC but no one showed significant clinical activity to exceed topotecan as 2 nd line chemotherapy.

\section{Amrubicin}

Amrubicin is a third-generation anthracycline and potent topoisomerase II inhibitor that showed superiority to topotecan in a Japanese population but not in western patients. [79,80] But it is noticeable, that to the trial that participate western population, there was an improvement in OS, to the refractory patients, that were treated with amrubicin. $[79,80]$ In another trial compared amrubicin with irinotecan and cisplatin, in the first line, did not demonstrate superiority for amrubicin. [81] And also when compared with etoposide and cisplatin did not show clinical benefit. [82]

\section{Targeted Therapies}

Due to discovery of many targeted and immunotherapy drugs in non-small cell lung cancer (NSCLC), the investigators tried to develop similar drugs and to SCLC but the results were disappointing. A variety of targeted therapies such as anti-GD3 immunization, metalloproteinase inhibitors, angiogenesis inhibitors (e.g. bevasizumab), GFR inhibitors, apoptosis promoters and p53 cancer vaccine have been previously examined as 1 st line treatment, but most of the trials failed to show improved PFS or OS. [82-87] There are current studies that are focusing on the Hedgehog pathway, epigenetic regulatory pathways, and DNA damage repair mediated by PARP1. [88,89] 


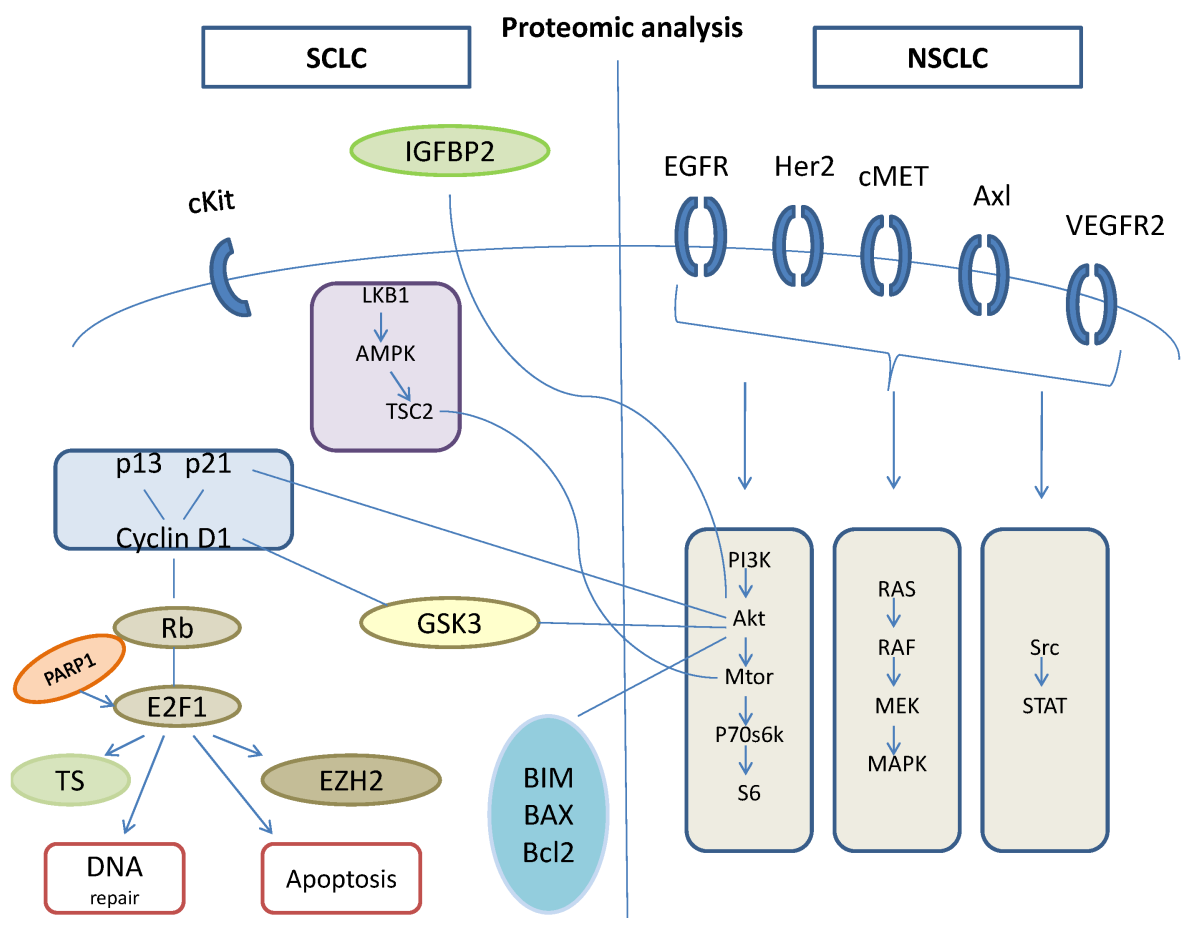

Figure 1. Proteomic analysis.

Although preclinical studies showed very hopeful potency of vismodegib, which is a Hedgehog inhibitor. When this drug combined with cisplatin and etoposide, did not show any superiority to OS or to PFS. [90] Another old drug this time, tested through a phase II, clinical trial, in which temozolomide administered in patients with relapsed sensitive or refractory small cell lung cancer, with assessment of methylguanine-DNA methyltransferase, and temozolomide showed activity in relapsed SCLC, especially in those patients with brain metastasis. [91] In other trial temozolomide administered for 5 days temozolomide in patients with relapsed small cell lung cancers with assessment of methylguanine-DNA methyltransferase and this trial showed that this dosage is tolerable and the drug is active in patients with relapsed SCLCs. [92] mTOR inhibitors act on intracellular serine/threonine protein kinases that regulate cell growth, cell proliferation, cell motility, cell survival, protein synthesis, and transcription. $[93,94]$ Temsirolimus and everolimus are the m TOR inhibitors that have been evaluated in SCLC, through clinical trials, either as maintenance therapy, or as a monotherapy in treatment of relapsed SCLC. $[95,96]$ The results of all the trials did not show improvement in OS or in PFS. Targeted therapies that are at this time under investigation are PARP inhibitors as the olaparib, the velaparib, the niraparib and the BMN673-PARP trap and the aurora kinases as the A MLN8237 and the B AZD1152-alisertib. [97,98] Also was not observed improvement in OS and when a target agent added to chemotherapy, as when added bevasizumab to paltinum etoposide combination for extensive-disease of SCLC. [58]

\section{Immunotherapy}

The tumor immunotherapy has the potential to settle and precipitate the immune system to recognize and extinguish the tumor cells. When ipilimumab administered in combination with paclitaxel and carboplatin in extensive-disease of SCLC, in the first-line therapy, the results were promisingimproved irPFS versus control. [99]

\section{Ongoing trials}

The clinical trials that are on-going are [100]:

- Cisplatin and Etoposide with or without Veliparib in Treating Patients with Extensive Stage Small Cell Lung Cancer or Metastatic Large Cell Neuroendocrine Non-small Cell Lung Cancer.

- This is a phase I, dose-escalation study of veliparib followed by a phase II study.

- Temozolomide with or without Veliparib in Treating Patients with Relapsed or Refractory Small Cell Lung Cancer.

- This randomized phase II trial studies how well temozolomide with or without veliparib works in treating patients with small cell lung cancer 
that has returned or does not respond to treatment.

- Topotecan Hydrochloride or Cyclodextrin-Based Polymer-Camptothecin CRLX101 in Treating Patients with Recurrent Small Cell Lung Cancer.

- This randomized phase II trial studies how well giving topotecan hydrochloride or cyclodextrinbased polymer-camptothecin CRLX101 works in treating patients with recurrent small cell lung cancer.

- Pegylated Irinotecan NKTR 102 in Treating Patients with Relapsed Small Cell Lung Cancer.

- This phase II trial studies how well pegylated irinotecan NKTR 102 works in treating patients with small cell lung cancer that has returned after a period of improvement.

- Pembrolizumab in Treating Patients with Extensive Stage Small Cell Lung Cancer After Completion of Combination Chemotherapy.

- This phase II trial studies how well pembrolizumab works in treating patients with extensive stage small cell lung cancer after completion of combination chemotherapy.

- Topotecan Hydrochloride and Doxorubicin Hydrochloride in Treating Patients with Small Cell Lung Cancer That Has Relapsed or Not Responded to Treatment.

- This phase I trial is studying the side effects and best dose of topotecan hydrochloride when given together with doxorubicin hydrochloride in treating patients with small cell lung cancer (SCLC) that has returned or not responded to treatment.

- Chloroquine as an Anti-Autophagy Drug in Stage IV Small Cell Lung Cancer (SCLC) Patients.

- Chloroquine might very well be able to increase overall survival in small cell lung cancer by sensitizing cells resistant to chemotherapy and radiotherapy.

\section{Conclusions}

The treatment of SCLC remains an important challenge for the investigators. In spite of the at least 40 clinical trials since the 1970s, the options for the combination of the chemotherapeutic agents remains the same, as for the past decades. All the trials did not demonstrate any significant change to the OS for the patients with SCLC, who submitted in therapy. Despite the fact that SCLC is heterogeneous, there have been reported tumor suppressors and oncogenes that target somatic mutations. These attempts are needed to be emphasized for the development of validated biomarkers in order to achieve a better impact on patient survival.

\section{Conflict of Interest}

None to declare.

\section{References}

1. Zarogoulidis K, Latsios D, Porpodis K, Zarogoulidis P, Darwiche K, Antoniou N, et al. New dilemmas in small-cell lung cancer TNM clinical staging. OncoTargets and therapy. 2013; 6: 539-47.

2. Murray N, Coy P, Pater JL, Hodson I, Arnold A, Zee BC, et al. Importance of timing for thoracic irradiation in the combined modality treatment of limited-stage small-cell lung cancer. The National Cancer Institute of Canada Clinical Trials Group. Journal of clinical oncology: official journal of the American Society of Clinical Oncology. 1993; 11: 336-44.

3. Shepherd FA, Crowley J, Van Houtte P, Postmus PE, Carney D, Chansky $\mathrm{K}$, et al. The International Association for the Study of Lung Cancer lung cancer staging project: proposals regarding the clinical staging of small cell lung cancer in the forthcoming (seventh) edition of the tumor, node, metastasis classification for lung cancer. Journal of thoracic oncology: official publication of the International Association for the Study of Lung Cancer. 2007; 2: 1067-77.

4. Ihde D, Souhami B, Comis R, Gregor A, Hansen H, Johnson B, et al. Small cell lung cancer. Lung cancer. 1997; 17 Suppl 1: S19-21.

5. Videtic GM, Stitt LW, Dar AR, Kocha WI, Tomiak AT, Truong PT, et al. Continued cigarette smoking by patients receiving concurrent chemoradiotherapy for limited-stage small-cell lung cancer is associated with decreased survival. Journal of clinical oncology: official journal of the American Society of Clinical Oncology. 2003; 21: 1544-9.

6. Giaccone G, Debruyne C, Felip E, Chapman PB, Grant SC, Millward M, et al. Phase III study of adjuvant vaccination with Bec2/bacille Calmette-Guerin in responding patients with limited-disease small-cell lung cancer (European Organisation for Research and Treatment of Cancer 08971-08971B; Silva Study). Journal of clinical oncology: official journal of the American Society of Clinical Oncology. 2005; 23: 6854-64.

7. Govindan R, Page N, Morgensztern D, Read W, Tierney R, Vlahiotis A, et al. Changing epidemiology of small-cell lung cancer in the United States over the last 30 years: analysis of the surveillance, epidemiologic, and end results database. Journal of clinical oncology: official journal of the American Society of Clinical Oncology. 2006; 24: 4539-44.

8. Gibbs AR, Thunnissen FB. Histological typing of lung and pleural tumours: third edition. Journal of clinical pathology. 2001; 54: 498-9.

9. Brambilla E, Travis WD, Colby TV, Corrin B, Shimosato Y. The new World Health Organization classification of lung tumours. The European respiratory journal, 2001; 18(6): 1059-1068.

10. Guinee DG, Jr., Fishback NF, Koss MN, Abbondanzo SL, Travis WD. The spectrum of immunohistochemical staining of small-cell lung carcinoma in specimens from transbronchial and open-lung biopsies. American journal of clinical pathology. 1994; 102: 406-14.

11. Zheng X, Liu D, Fallon JT, Zhong M. Distinct genetic alterations in small cell carcinoma from different anatomic sites. Experimental hematology \& oncology. 2015; $4: 2$.

12. Osterlind $\mathrm{K}$, Hansen $\mathrm{M}$, Hansen $\mathrm{HH}$, Dombernowsky $\mathrm{P}$, Rorth M. Treatment policy of surgery in small cell carcinoma of the lung: retrospective analysis of a series of 874 consecutive patients. Thorax. 1985; 40: 272-7.

13. Shepherd FA, Ginsberg RJ, Patterson GA, Evans WK, Feld R. A prospective study of adjuvant surgical resection after chemotherapy for limited small cell lung cancer. A University of Toronto Lung Oncology Group study. The Journal of thoracic and cardiovascular surgery. 1989; 97: 177-86.

14. Prasad US, Naylor AR, Walker WS, Lamb D, Cameron EW, Walbaum PR. Long term survival after pulmonary resection for small cell carcinoma of the lung. Thorax. 1989; 44: 784-7.

15. Smit EF, Groen HJ, Timens W, de Boer WJ, Postmus PE. Surgical resection for small cell carcinoma of the lung: a retrospective study. Thorax. 1994; 49: 20-2.

16. Chandra V, Allen MS, Nichols FC, 3rd, Deschamps C, Cassivi SD, Pairolero PC. The role of pulmonary resection in small cell lung cancer. Mayo Clinic proceedings. 2006; 81: 619-24.

17. Comis RL, Friedland DM, Good BC. Small-cell lung cancer: a perspective on the past and a preview of the future. Oncology. 1998; 12: 44-50. 
18. Agra Y, Pelayo M, Sacristan M, Sacristan A, Serra C, Bonfill X. Chemotherapy versus best supportive care for extensive small cell lung cancer. The Cochrane database of systematic reviews. 2003: CD001990.

19. Pignon JP, Arriagada R, Ihde DC, Johnson DH, Perry MC, Souhami RL, et al. A meta-analysis of thoracic radiotherapy for small-cell lung cancer. The New England journal of medicine. 1992; 327: 1618-24.

20. Warde P, Payne D. Does thoracic irradiation improve survival and local control in limited-stage small-cell carcinoma of the lung? A meta-analysis. Journal of clinical oncology: official journal of the American Society of Clinical Oncology. 1992; 10: 890-5.

21. McCracken JD, Janaki LM, Crowley JJ, Taylor SA, Giri PG, Weiss GB, et al. Concurrent chemotherapy/radiotherapy for limited small-cell lung carcinoma: a Southwest Oncology Group Study. Journal of clinical oncology: official journal of the American Society of Clinical Oncology. 1990; 8: 892-8.

22. Takada M, Fukuoka M, Kawahara M, Sugiura T, Yokoyama A, Yokota S, et al. Phase III study of concurrent versus sequential thoracic radiotherapy in combination with cisplatin and etoposide for limited-stage small-cell lung cancer: results of the Japan Clinical Oncology Group Study 9104. Journal of clinical oncology: official journal of the American Society of Clinical Oncology. 2002; 20: 3054-60.

23. Johnson BE, Bridges JD, Sobczeck M, Gray J, Linnoila RI, Gazdar AF, et al. Patients with limited-stage small-cell lung cancer treated with concurrent twice-daily chest radiotherapy and etoposide/cisplatin followed by cyclophosphamide, doxorubicin, and vincristine. Journal of clinical oncology: official journal of the American Society of Clinical Oncology. 1996; 14: 806-13.

24. Spiro SG, James LE, Rudd RM, Trask CW, Tobias JS, Snee M, et al. Early compared with late radiotherapy in combined modality treatment for limited disease small-cell lung cancer: a London Lung Cancer Group multicenter randomized clinical trial and meta-analysis. Journal of clinical oncology: official journal of the American Society of Clinical Oncology. 2006; 24: 3823-30.

25. De Ruysscher D, Pijls-Johannesma M, Vansteenkiste J, Kester A, Rutten I, Lambin P. Systematic review and meta-analysis of randomised, controlled trials of the timing of chest radiotherapy in patients with limited-stage, small-cell lung cancer. Annals of oncology: official journal of the European Society for Medical Oncology / ESMO. 2006; 17: 543-52.

26. Giaccone G, Dalesio O, McVie GJ, Kirkpatrick A, Postmus PE, Burghouts JT, et al. Maintenance chemotherapy in small-cell lung cancer: long-term results of a randomized trial. European Organization for Research and Treatment of Cancer Lung Cancer Cooperative Group. Journal of clinical oncology: official journal of the American Society of Clinical Oncology. 1993; 11: 1230-40.

27. Goodman GE, Crowley JJ, Blasko JC, Livingston RB, Beck TM, Demattia $\mathrm{MD}$, et al. Treatment of limited small-cell lung cancer with etoposide and cisplatin alternating with vincristine, doxorubicin, and cyclophosphamide versus concurrent etoposide, vincristine, doxorubicin, and cyclophosphamide and chest radiotherapy: a Southwest Oncology Group Study. Journal of clinical oncology: official journal of the American Society of Clinical Oncology. 1990; 8: 39-47.

28. Fukuoka M, Furuse K, Saijo N, Nishiwaki Y, Ikegami H, Tamura T, et al. Randomized trial of cyclophosphamide, doxorubicin, and vincristine versus cisplatin and etoposide versus alternation of these regimens in small-cell lung cancer. Journal of the National Cancer Institute. 1991; 83: 855-61.

29. Bleehen NM, Girling DJ, Machin D, Stephens RJ. A randomised trial of three or six courses of etoposide cyclophosphamide methotrexate and vincristine or six courses of etoposide and ifosfamide in small cell lung cancer (SCLC). II: Quality of life. Medical Research Council Lung Cancer Working Party. British journal of cancer. 1993; 68: 1157-66.

30. Sculier JP, Paesmans M, Bureau G, Giner V, Lecomte J, Michel J, et al. Randomized trial comparing induction chemotherapy versus induction chemotherapy followed by maintenance chemotherapy in small-cell lung cancer. European Lung Cancer Working Party. Journal of clinical oncology: official journal of the American Society of Clinical Oncology. 1996; 14: 2337-44.

31. Fried DB, Morris DE, Poole C, Rosenman JG, Halle JS, Detterbeck FC, et al. Systematic review evaluating the timing of thoracic radiation therapy in combined modality therapy for limited-stage small-cell lung cancer. Journal of clinical oncology: official journal of the American Society of Clinical Oncology. 2004; 22: 4837-45.

32. Kubota K, Hida T, Ishikura S, Mizusawa J, Nishio M, Kawahara M, et al. Etoposide and cisplatin versus irinotecan and cisplatin in patients with limited-stage small-cell lung cancer treated with etoposide and cisplatin plus concurrent accelerated hyperfractionated thoracic radiotherapy
(JCOG0202): a randomised phase 3 study. The Lancet Oncology. 2014; 15: 106-13.

33. Turrisi AT, 3rd, Kim K, Blum R, Sause WT, Livingston RB, Komaki R, et al. Twice-daily compared with once-daily thoracic radiotherapy in limited small-cell lung cancer treated concurrently with cisplatin and etoposide. The New England journal of medicine. 1999; 340: 265-71.

34. Huncharek M, McGarry R. A meta-analysis of the timing of chest irradiation in the combined modality treatment of limited-stage small cell lung cancer. The oncologist. 2004; 9: 665-72.

35. Pijls-Johannesma MC, De Ruysscher D, Lambin P, Rutten I, Vansteenkiste JF. Early versus late chest radiotherapy for limited stage small cell lung cancer. The Cochrane database of systematic reviews. 2005: CD004700.

36. De Ruysscher D, Pijls-Johannesma M, Bentzen SM, Minken A, Wanders $\mathrm{R}$, Lutgens $\mathrm{L}$, et al. Time between the first day of chemotherapy and the last day of chest radiation is the most important predictor of survival in limited-disease small-cell lung cancer. Journal of clinical oncology: official journal of the American Society of Clinical Oncology. 2006; 24: 1057-63.

37. Turrisi AT, 3rd, Glover DJ. Thoracic radiotherapy variables: influence on local control in small cell lung cancer limited disease. International journal of radiation oncology, biology, physics. 1990; 19: 1473-9.

38. Bogart JA, Herndon JE, 2nd, Lyss AP, Watson D, Miller AA, Lee ME, et al. 70 Gy thoracic radiotherapy is feasible concurrent with chemotherapy for limited-stage small-cell lung cancer: analysis of Cancer and Leukemia Group B study 39808. International journal of radiation oncology, biology, physics. 2004; 59: 460-8.

39. Salama JK, Hodgson L, Pang H, Urbanic JJ, Blackstock AW, Schild SE, et al. A pooled analysis of limited-stage small-cell lung cancer patients treated with induction chemotherapy followed by concurrent platinum-based chemotherapy and 70 Gy daily radiotherapy: CALGB 30904. Journal of thoracic oncology: official publication of the International Association for the Study of Lung Cancer. 2013; 8: 1043-9.

40. Choi NC, Herndon JE, 2nd, Rosenman J, Carey RW, Chung CT, Bernard $\mathrm{S}$, et al. Phase I study to determine the maximum-tolerated dose of radiation in standard daily and hyperfractionated-accelerated twice-daily radiation schedules with concurrent chemotherapy for limited-stage small-cell lung cancer. Journal of clinical oncology: official journal of the American Society of Clinical Oncology. 1998; 16: 3528-36.

41. Miller AA, Wang XF, Bogart JA, Hodgson LD, Rocha Lima CM, Radford JE, et al. Phase II trial of paclitaxel-topotecan-etoposide followed by consolidation chemoradiotherapy for limited-stage small cell lung cancer: CALGB 30002. Journal of thoracic oncology: official publication of the International Association for the Study of Lung Cancer. 2007; 2: 645-51.

42. Kelley MJ, Bogart JA, Hodgson LD, Ansari RH, Atkins JN, Pang H, et al. Phase II study of induction cisplatin and irinotecan followed by concurrent carboplatin, etoposide, and thoracic radiotherapy for limited-stage small-cell lung cancer, CALGB 30206. Journal of thoracic oncology: official publication of the International Association for the Study of Lung Cancer. 2013; 8: 102-8.

43. Urban T, Lebeau B, Chastang C, Leclerc P, Botto MJ, Sauvaget J. Superior vena cava syndrome in small-cell lung cancer. Archives of internal medicine. 1993; 153: 384-7.

44. Wurschmidt F, Bunemann H, Heilmann HP. Small cell lung cancer with and without superior vena cava syndrome: a multivariate analysis of prognostic factors in 408 cases. International journal of radiation oncology, biology, physics. 1995; 33: 77-82.

45. Nugent JL, Bunn PA, Jr., Matthews MJ, Ihde DC, Cohen MH, Gazdar A, et al. CNS metastases in small cell bronchogenic carcinoma: increasing frequency and changing pattern with lengthening survival. Cancer. 1979; 44: 1885-93.

46. Auperin A, Arriagada R, Pignon JP, Le Pechoux C, Gregor A, Stephens RJ, et al. Prophylactic cranial irradiation for patients with small-cell lung cancer in complete remission. Prophylactic Cranial Irradiation Overview Collaborative Group. The New England journal of medicine. 1999; 341: 476-84.

47. Roth BJ, Johnson DH, Einhorn LH, Schacter LP, Cherng NC, Cohen HJ, et al. Randomized study of cyclophosphamide, doxorubicin, and vincristine versus etoposide and cisplatin versus alternation of these two regimens in extensive small-cell lung cancer: a phase III trial of the Southeastern Cancer Study Group. Journal of clinical oncology: official journal of the American Society of Clinical Oncology. 1992; 10: 282-91.

48. Pujol JL, Carestia L, Daures JP. Is there a case for cisplatin in the treatment of small-cell lung cancer? A meta-analysis of randomized trials of a cisplatin-containing regimen versus a regimen without this alkylating agent. British journal of cancer. 2000; 83: 8-15. 
49. Amarasena IU, Walters JA, Wood-Baker R, Fong K. Platinum versus non-platinum chemotherapy regimens for small cell lung cancer. The Cochrane database of systematic reviews. 2008: CD006849.

50. Controlled trial of twelve versus six courses of chemotherapy in the treatment of small-cell lung cancer. Report to the Medical Research Council by its Lung Cancer Working Party. British journal of cancer. 1989; 59: 584-90.

51. Hanna N, Bunn PA, Jr., Langer C, Einhorn L, Guthrie T, Jr., Beck T, et al. Randomized phase III trial comparing irinotecan/cisplatin with etoposide/cisplatin in patients with previously untreated extensive-stage disease small-cell lung cancer. Journal of clinical oncology: official journal of the American Society of Clinical Oncology. 2006; 24: 2038-43.

52. Lara PN, Jr., Natale R, Crowley J, Lenz HJ, Redman MW, Carleton JE, et al. Phase III trial of irinotecan/cisplatin compared with etoposide/cisplatin in extensive-stage small-cell lung cancer: clinical and pharmacogenomic results from SWOG S0124. Journal of clinical oncology: official journal of the American Society of Clinical Oncology. 2009; 27: 2530-5.

53. Eckardt JR, von Pawel J, Papai Z, Tomova A, Tzekova V, Crofts TE, et al. Open-label, multicenter, randomized, phase III study comparing oral topotecan/cisplatin versus etoposide/cisplatin as treatment for chemotherapy-naive patients with extensive-disease small-cell lung cancer. Journal of clinical oncology: official journal of the American Society of Clinical Oncology. 2006; 24: 2044-51.

54. Mavroudis D, Papadakis E, Veslemes M, Tsiafaki X, Stavrakakis J, Kouroussis C, et al. A multicenter randomized clinical trial comparing paclitaxel-cisplatin-etoposide versus cisplatin-etoposide as first-line treatment in patients with small-cell lung cancer. Annals of oncology: official journal of the European Society for Medical Oncology / ESMO. 2001; 12: 463-70.

55. Niell HB, Herndon JE, 2nd, Miller AA, Watson DM, Sandler AB, Kelly K, et al. Randomized phase III intergroup trial of etoposide and cisplatin with or without paclitaxel and granulocyte colony-stimulating factor in patients with extensive-stage small-cell lung cancer: Cancer and Leukemia Group B Trial 9732. Journal of clinical oncology: official journal of the American Society of Clinical Oncology. 2005; 23: 3752-9.

56. Loehrer PI, Sr., Ansari R, Gonin R, Monaco F, Fisher W, Sandler A, et al. Cisplatin plus etoposide with and without ifosfamide in extensive small-cell lung cancer: a Hoosier Oncology Group study. Journal of clinical oncology: official journal of the American Society of Clinical Oncology. 1995; 13: 2594-9.

57. Lee SM, James L, Buchler T, Snee M, Ellis P, Hackshaw A. Phase II trial of thalidomide with chemotherapy and as maintenance therapy for patients with poor prognosis small-cell lung cancer. Lung cancer. 2008; 59: 364-8.

58. Spigel DR, Townley PM, Waterhouse DM, Fang L, Adiguzel I, Huang JE, et al. Randomized phase II study of bevacizumab in combination with chemotherapy in previously untreated extensive-stage small-cell lung cancer: results from the SALUTE trial. Journal of clinical oncology: official journal of the American Society of Clinical Oncology. 2011; 29: 2215-22.

59. Spiro SG, Souhami RL, Geddes DM, Ash CM, Quinn H, Harper PG, et al. Duration of chemotherapy in small cell lung cancer: a Cancer Research Campaign trial. British journal of cancer. 1989; 59: 578-83.

60. Rossi A, Garassino MC, Cinquini M, Sburlati P, Di Maio M, Farina G, et al. Maintenance or consolidation therapy in small-cell lung cancer: a systematic review and meta-analysis. Lung cancer. 2010; 70: 119-28.

61. Bozcuk $\mathrm{H}$, Artac $\mathrm{M}$, Ozdogan $\mathrm{M}$, Savas B. Does maintenance/consolidation chemotherapy have a role in the management of small cell lung cancer (SCLC)? A metaanalysis of the published controlled trials. Cancer. 2005; 104: 2650-7.

62. Ready NE, Pang HH, Gu L, Otterson GA, Thomas SP, Miller AA, et al. Chemotherapy With or Without Maintenance Sunitinib for Untreated Extensive-Stage Small-Cell Lung Cancer: A Randomized, Double-Blind, Placebo-Controlled Phase II Study-CALGB 30504 (Alliance). Journal of clinical oncology: official journal of the American Society of Clinical Oncology. 2015.

63. Thatcher N, Girling DJ, Hopwood P, Sambrook RJ, Qian W, Stephens RJ. Improving survival without reducing quality of life in small-cell lung cancer patients by increasing the dose-intensity of chemotherapy with granulocyte colony-stimulating factor support: results of a British Medical Research Council Multicenter Randomized Trial. Medical Research Council Lung Cancer Working Party. Journal of clinical oncology: official journal of the American Society of Clinical Oncology. 2000; 18: 395-404.
64. James LE, Gower NH, Rudd RM, Spiro SG, Harper PG, Trask CW, et al. A randomised trial of low-dose/high-frequency chemotherapy as palliative treatment of poor-prognosis small-cell lung cancer: a Cancer research Campaign trial. British journal of cancer. 1996; 73: 1563-8.

65. Pujol JL, Douillard JY, Riviere A, Quoix E, Lagrange JL, Berthaud P, et al. Dose-intensity of a four-drug chemotherapy regimen with or without recombinant human granulocyte-macrophage colony-stimulating factor in extensive-stage small-cell lung cancer: a multicenter randomized phase III study. Journal of clinical oncology: official journal of the American Society of Clinical Oncology. 1997; 15: 2082-9.

66. Ardizzoni A, Tjan-Heijnen VC, Postmus PE, Buchholz E, Biesma B, Karnicka-Mlodkowska $\mathrm{H}$, et al. Standard versus intensified chemotherapy with granulocyte colony-stimulating factor support in small-cell lung cancer: a prospective European Organization for Research and Treatment of Cancer-Lung Cancer Group Phase III Trial-08923. Journal of clinical oncology: official journal of the American Society of Clinical Oncology. 2002; 20: 3947-55.

67. Fukuoka M, Masuda N, Negoro S, Matsui K, Yana T, Kudoh S, et al. CODE chemotherapy with and without granulocyte colony-stimulating factor in small-cell lung cancer. British journal of cancer. 1997; 75: 306-9.

68. Woll PJ, Hodgetts J, Lomax L, Bildet F, Cour-Chabernaud V, Thatcher N. Can cytotoxic dose-intensity be increased by using granulocyte colony-stimulating factor? A randomized controlled trial of lenograstim in small-cell lung cancer. Journal of clinical oncology: official journal of the American Society of Clinical Oncology. 1995; 13: 652-9.

69. Steward WP, von Pawel J, Gatzemeier U, Woll P, Thatcher N, Koschel G, et al. Effects of granulocyte-macrophage colony-stimulating factor and dose intensification of V-ICE chemotherapy in small-cell lung cancer: a prospective randomized study of 300 patients. Journal of clinical oncology: official journal of the American Society of Clinical Oncology. 1998; 16: 642-50.

70. Wu C, Wang T, Wang J, Qu B, Wang H, Hu Y. Effect of radiotherapy on the treatment of patients with extensive stage small cell lung cancer. Genetics and molecular research: GMR. 2014; 13: 8577-85.

71. Slotman BJ, van Tinteren H, Praag JO, Knegjens JL, El Sharouni SY, Hatton $\mathrm{M}$, et al. Use of thoracic radiotherapy for extensive stage small-cell lung cancer: a phase 3 randomised controlled trial. Lancet. 2015; 385: 36-42.

72. Slotman B, Faivre-Finn C, Kramer G, Rankin E, Snee M, Hatton M, et al. Prophylactic cranial irradiation in extensive small-cell lung cancer. The New England journal of medicine. 2007; 357: 664-72.

73. Le Pechoux C, Laplanche A, Faivre-Finn C, Ciuleanu T, Wanders R, Lerouge $\mathrm{D}$, et al. Clinical neurological outcome and quality of life among patients with limited small-cell cancer treated with two different doses of prophylactic cranial irradiation in the intergroup phase III trial (PCI99-01, EORTC 22003-08004, RTOG 0212 and IFCT 99-01). Annals of oncology: official journal of the European Society for Medical Oncology / ESMO. 2011; 22: 1154-63.

74. Carden $\mathrm{CP}, \mathrm{O}^{\prime}$ Brien ME. Small-cell lung cancer, getting smaller but still difficult to treat. Journal of thoracic oncology: official publication of the International Association for the Study of Lung Cancer. 2008; 3: 103-4.

75. O'Brien ME, Ciuleanu TE, Tsekov H, Shparyk Y, Cucevia B, Juhasz G, et al. Phase III trial comparing supportive care alone with supportive care with oral topotecan in patients with relapsed small-cell lung cancer. Journal of clinical oncology: official journal of the American Society of Clinical Oncology. 2006; 24: 5441-7.

76. Postmus PE, Berendsen HH, van Zandwijk N, Splinter TA, Burghouts JT, Bakker W. Retreatment with the induction regimen in small cell lung cancer relapsing after an initial response to short term chemotherapy. European journal of cancer \& clinical oncology. 1987; 23: 1409-11.

77. Eckardt JR, von Pawel J, Pujol JL, Papai Z, Quoix E, Ardizzoni A, et al. Phase III study of oral compared with intravenous topotecan as second-line therapy in small-cell lung cancer. Journal of clinical oncology: official journal of the American Society of Clinical Oncology. 2007; 25: 2086-92.

78. von Pawel J, Schiller JH, Shepherd FA, Fields SZ, Kleisbauer JP, Chrysson NG, et al. Topotecan versus cyclophosphamide, doxorubicin, and vincristine for the treatment of recurrent small-cell lung cancer. Journal of clinical oncology: official journal of the American Society of Clinical Oncology. 1999; 17: 658-67.

79. Inoue A, Sugawara S, Yamazaki K, Maemondo M, Suzuki T, Gomi K, et al. Randomized phase II trial comparing amrubicin with topotecan in patients with previously treated small-cell lung cancer: North Japan Lung Cancer Study Group Trial 0402. Journal of clinical oncology: official journal of the American Society of Clinical Oncology. 2008; 26: 5401-6. 
80. von Pawel J, Jotte R, Spigel DR, O'Brien ME, Socinski MA, Mezger J, et al. Randomized phase III trial of amrubicin versus topotecan as second-line treatment for patients with small-cell lung cancer. Journal of clinical oncology: official journal of the American Society of Clinical Oncology. 2014; 32: 4012-9.

81. Satouchi M, Kotani Y, Shibata T, Ando M, Nakagawa K, Yamamoto N, et al. Phase III study comparing amrubicin plus cisplatin with irinotecan plus cisplatin in the treatment of extensive-disease small-cell lung cancer: JCOG 0509. Journal of clinical oncology: official journal of the American Society of Clinical Oncology. 2014; 32: 1262-8.

82. O'Brien ME, Konopa K, Lorigan P, Bosquee L, Marshall E, Bustin F, et al. Randomised phase II study of amrubicin as single agent or in combination with cisplatin versus cisplatin etoposide as first-line treatment in patients with extensive stage small cell lung cancer EORTC 08062. European journal of cancer. 2011; 47: 2322-30.

83. Kallio JP, Hopkins-Donaldson S, Baker AH, Kahari VM. TIMP-3 promotes apoptosis in nonadherent small cell lung carcinoma cells lacking functional death receptor pathway. International journal of cancer Journal international du cancer. 2011; 128: 991-6.

84. Pujol JL, Lavole A, Quoix E, Molinier O, Souquet PJ, Barlesi F, et al. Randomized phase II-III study of bevacizumab in combination with chemotherapy in previously untreated extensive small-cell lung cancer: results from the IFCT-0802 trialdagger. Annals of oncology: official journal of the European Society for Medical Oncology / ESMO. 2015; 26: 908-14.

85. Mulligan LM, Timmer T, Ivanchuk SM, Campling BG, Young LC, Rabbitts $\mathrm{PH}$, et al. Investigation of the genes for RET and its ligand complex, GDNF/GFR alpha-I, in small cell lung carcinoma. Genes, chromosomes \& cancer. 1998; 21: 326-32.

86. Mortenson MM, Schlieman MG, Virudachalam S, Lara PN, Gandara DG, Davies AM, et al. Reduction in BCL-2 levels by $26 \mathrm{~S}$ proteasome inhibition with bortezomib is associated with induction of apoptosis in small cell lung cancer. Lung cancer. 2005; 49: 163-70.

87. Chiappori AA, Soliman H, Janssen WE, Antonia SJ, Gabrilovich DI. INGN-225: a dendritic cell-based p53 vaccine (Ad.p53-DC) in small cell lung cancer: observed association between immune response and enhanced chemotherapy effect. Expert opinion on biological therapy. 2010; 10: 983-91.

88. Byers LA, Wang J, Nilsson MB, Fujimoto J, Saintigny P, Yordy J, et al. Proteomic profiling identifies dysregulated pathways in small cell lung cancer and novel therapeutic targets including PARP1. Cancer discovery. 2012; 2: 798-811.

89. Cardnell RJ, Feng Y, Diao L, Fan YH, Masrorpour F, Wang J, et al. Proteomic markers of DNA repair and PI3K pathway activation predict response to the PARP inhibitor BMN 673 in small cell lung cancer. Clinical cancer research: an official journal of the American Association for Cancer Research. 2013; 19: 6322-8.

90. Erdem GU, Sendur MA, Ozdemir NY, Yazici O, Zengin N. A comprehensive review of the role of the hedgehog pathway and vismodegib in the management of basal cell carcinoma. Current medical research and opinion. 2015; 31: 743-56.

91. Pietanza MC, Kadota K, Huberman K, Sima CS, Fiore JJ, Sumner DK, et al. Phase II trial of temozolomide in patients with relapsed sensitive or refractory small cell lung cancer, with assessment of methylguanine-DNA methyltransferase as a potential biomarker. Clinical cancer research: an official journal of the American Association for Cancer Research. 2012; 18: 1138-45.

92. Zauderer MG, Drilon A, Kadota K, Huberman K, Sima CS, Bergagnini I, et al. Trial of a 5-day dosing regimen of temozolomide in patients with relapsed small cell lung cancers with assessment of methylguanine-DNA methyltransferase. Lung cancer. 2014; 86: 237-40.

93. Lazaridis G, Lambaki S, Karayannopoulou G, Eleftheraki AG, Papaspirou I, Bobos M, et al. Prognostic and predictive value of p-Akt, EGFR, and p-mTOR in early breast cancer. Strahlentherapie und Onkologie: Organ der Deutschen Rontgengesellschaft [et al]. 2014; 190: 636-8, 40-5

94. Zarogoulidis P, Lampaki S, Turner JF, Huang H, Kakolyris S, Syrigos K, et al. mTOR pathway: A current, up-to-date mini-review (Review). Oncology letters. 2014; 8: 2367-70.

95. Pandya KJ, Dahlberg S, Hidalgo M, Cohen RB, Lee MW, Schiller JH, et al. A randomized, phase II trial of two dose levels of temsirolimus (CCI-779) in patients with extensive-stage small-cell lung cancer who have responding or stable disease after induction chemotherapy: a trial of the Eastern Cooperative Oncology Group (E1500). Journal of thoracic oncology: official publication of the International Association for the Study of Lung Cancer. 2007; 2: 1036-41.
96. Tarhini A, Kotsakis A, Gooding W, Shuai Y, Petro D, Friedland D, et al. Phase II study of everolimus (RAD001) in previously treated small cell lung cancer. Clinical cancer research: an official journal of the American Association for Cancer Research. 2010; 16: 5900-7.

97. Tangutoori S, Baldwin P, Sridhar S. PARP inhibitors: A new era of targeted therapy. Maturitas. 2015; 81: 5-9.

98. Melichar B, Adenis A, Lockhart AC, Bennouna J, Dees EC, Kayaleh O, et al. Safety and activity of alisertib, an investigational aurora kinase A inhibitor, in patients with breast cancer, small-cell lung cancer, non-small-cell lung cancer, head and neck squamous-cell carcinoma, and gastro-oesophageal adenocarcinoma: a five-arm phase 2 study. The Lancet Oncology. 2015; 16: 395-405.

99. Reck M, Bondarenko I, Luft A, Serwatowski P, Barlesi F, Chacko R, et al. Ipilimumab in combination with paclitaxel and carboplatin as first-line therapy in extensive-disease-small-cell lung cancer: results from a randomized, double-blind, multicenter phase 2 trial. Annals of oncology: official journal of the European Society for Medical Oncology / ESMO. 2013; 24: 75-83.

100. [Internet] https://www.centerwatch.com/clinical-trials/listings/condit ion/720/small-cell-lung-cancer 